\title{
A major boost to the website performance of up-scale hotels in Vietnam
}

\author{
Nga Thi Vo \\ Faculty of Economics and Management, Tomas Bata University in Zlin, Czech Republic \\ Based by Faculty of Tourism, Hoa Sen University Vietnam \\ ngavongoc789@gmail.com \\ Miloslava CHOVANCOVÁ \\ Faculty of Economics and Management, Tomas Bata University in Zlin, Czech Republic \\ chovancova@utb.cz \\ Ho Thanh TRI \\ Faculty of Economics and Management, Tomas Bata University in Zlin, Czech Republic \\ hothanhtri@gmail.com
}

\begin{abstract}
The study aims to enhance the customer experience on hotel websites in the context of venue's booking channels to others. The online filed survey is conducted with 321 internet bookers. The exploratory factor analysis is adopted to analyze the data. The progression of customer satisfaction proceeds in a linear fashion on luxury (ranking from 4-star to 5-star hotels) websites. Moreover, the study reveals how hotel website performance would affect the levels of customer attitude and its sustainable development in the context of perceived e-service quality. The exploratory results show that customer satisfaction in online environment has identical processes in the context of up-scale hotel industry. The female group compared to male group, has more sensitive to perceive the impact of functionality of lodging website in developing customer satisfaction. Caution is advised in generalizing findings of this study due to stratified sampling even though the study confirms results of previously conducted studies. This study provides practical tips for website sustainable progress especially for hotel management to pay more attention to the e-service formation process. Therefore, the appropriate marketing strategy can be established to fill gender specific expectations towards individual degree of customer satisfaction.
\end{abstract}

Keywords: booking, customer satisfaction, hotel website, e-service quality, luxury hotel.

Please cite the article as follows: Vo, N.T., Chovancová, M, Tri, H.T. (2019), "A major boost to the website performance of up-scale hotels in Vietnam", Management \& Marketing. Challenges for the Knowledge Society, Vol. 14, No. 1, pp. 14-30. DOI: 10.2478/mmcks-2019-0002.

\section{Introduction}

The growth of online users and online transactions gives clear evidence that the internet is currently the hub of commercial environment. There are 4 billion internet users around the world in which more than 3 billion people use social media each month especially mobile devices have been accessed as their chosen platform (McDonald, 2018). The online travel booking segment has earned revenue to US\$345,567m in 2018 and United State got highest revenue at US\$93,679m compared to global (Anonymous, statista, 2018). In the accommodation context, hotel revenue has amounted to US\$142,013m in 2018 and is expected to result in a market volume of US\$193,851 m by 2023 (Anonymous, Statista, 2018). 
The average revenue per user in 2018 (ARPU) hits to US\$263.23 and United State stands still as the most revenue of US\$43,987m in global comparison (Anonymous, Statista, 2018). Capturing this lucrative online market, hotel and tourism managements have been and would continue, boosting the competitive advantages by emphasizing their resources on the virtual market.

In Vietnam market, the development of e-commerce has become fantastic possible. The online travel booking segment in 2018 has earned revenue of US\$671m including package holidays, private vacation rentals and particularly hotel rooms have got volume of US \$493mil (Anonymous, Statistica, 2018). The smartphone users in 2016 have increased $72 \%$ of the population using internet to search for travel-related products and services especially $48 \%$ of searchers looked for hotel destinations (Anonymous, Vietnamnews, 2017). The skyrocketing growth of online consumer purchases offers both threats and chances for hospitality and tourism enterprises. It is therefore imperative for lodging industry to adapt the Internet as an effective communication channel with its customers (Díaz \& Koutra, 2013).

Taking into account the competitive hotel business environment, hoteliers aim to develop its website as a dynamic marketing tool and utilize it in order to influence its customers' decision making (Martín \& Herrero, 2012). Sustaining an effective trusted website is crucial for establishment to both attract and obtain customer loyalty (Wang, et al., 2015). Because, e-Trust positively impacts online booking intentions in economy hotel website (Li, Peng, Jiang, \& Law, 2017). So, hotel website is the representative of hotel service quality via the first contact of potential customers. The online lookers are influenced by the information displayed on the Internet sources, hotel website and social media (Ferguson, 2014) including incentive information, friendly interface and usage especially trustworthy information sources to provide for online users (Ahmad \& Sun, 2018). However, is it acceptable if anything is displayed on the website? How customers' perception towards hotel website's interactivity would influence their perceive value then motivate them to reload the hotel website afterwards (Abdullah D. J., 2016). Consequently, they would book service or a room on the hotel website or suggest others to visit the site if they were happy with the websites and e-service of the hotel (Weber N. \&., 2005)

All in all, the researchers use the questionnaire via online and offline approaches to seek for 321 valid customers' evaluation and preferences towards the performance of hotel website which is significant booking channel to impact the online bookers. It is the major cause of this study. In this regard, the previous studies have mentioned the shopping path of the browser-to-search-engine model, but critical role of hotel website in the context of maintaining and boosting the purchase probabilities and sustainable development of hotel website in the tourism services towards the luxury hotels (from 4-star to 5-star hotels) in Vietnam. Based on those gaps in minds, we believe that a greater understanding of customer's perception towards satisfaction on perceive service quality concerning the major factors that may effect the future growth of hotel website service. It will not be only conceptually to the literature regarding hotel website service quality, but also be practically valuable to potential hotel performance. A range of factors was analysed to measure the level of customer satisfaction towards ways possible for up scale hotels to increase service performance of the websites in the future. We specifically examine three considerations below:

(1) factors effect online bookers towards luxury hotel websites quality 
(2) ways to increase level of customer satisfaction towards perceive service quality on luxury hotel websites

(3) to what extent the different gender may effect on purchase decision making towards perceive service quality on luxury hotel websites

\section{Literature review \\ Hotel website service quality}

It is irrefutable that maintaining hotel website in good order from online viewers' perspective is the hotel management and marketing's responsibility to make primary accessible to everyone. The reason is that a customer's adjustment or evaluation hotel service quality very much depends on the contribution made by its well designed site which is in well order.

Liu et al. first introduced the concept of "website quality" into the electronic commerce. They explained that the service quality issues in the design of web sites correlated positively with the marketing and information systems research constructs (Liu, Arnett, \& Litecky, 2000). But the constructors were only shown as significant to well designed web sites for consumer- oriented electronic commerce. The relationship of ecommerce behaviour and website quality is an important antecedent of information customer satisfaction (Jeong, Oh, \& Gregoire, 2003). There was minor problems of usability existed on the Web sites of Hong Kong hotels without significant difference was found among luxury, mid-priced, and economy hotels (Yeung \& Law, 2006). The study of the functionality of international chain hotel websites performance in Hong Kong, Shanghai and Beijing argued that the functionality has taken as the most influencer to determine the success of hotel website included customer's purchase intention and usage (Ma, Law, \& Ye, 2008).

Bai et al observed the evidence via questionnaire from 180/300 Chinese online visitors who have stayed in 3 star to 5 star hotels agreed that website quality has a direct and positive impact on customer satisfaction and purchase intentions (Bai, Law, \& Wen, 2008). But these random samples got unclear significant results which represent a vertical range of the lodging industry such as luxury, upscale, mid-scale and economy hotel segment. Till 2010, Lee \& Morrison reported that web sites of the 14 Korean upscale hotels perform slightly better than their US counterparts and most upscale hotels in both countries are not effectively using web sites from the marketing and upscale hotel perspectives (Lee \& Morrison, 2010). Analysing the weights of hotel website functionality in Hongkong found that "Reservation" is the most important criterion functionality of hotel website (Ip, Law, \& Lee, 2012). So, the hotel website boosts the purchase probability throughout the well design, efficient and effective functionality of the selling of hotel room and service

There are numerous academic researchers have drawn attention to details to obtain customer satisfaction. Especially the original and contemporary aims have been explored in order to increase numbers of hotel bookers on the internet. In the context of hotel website quality, the quality was identified as purchase stage (Davidow \& Uttal, 1989). It mediated the relationship between other factors and customer satisfaction (Zeithaml, Parasuraman, \& L.L.Berry, 1990). Consequently, the service quality was a core value for hotel services (Li, Ye, \& Law, 2013). In addition, the level of customer satisfaction in the online service context was associated with e-service such as web page quality and guest comments (Zhao, $\mathrm{Xu}$, \& Wang, 2018). However, some viewers distrusted the comments on website (Wasim Ahmad, 2018). 
Because online trust was as a mediator to study the impact of hotel website quality (Wang, Lawa, Guillet, Hung, \& Fong, 2015) and lookers' attitude was impacted by the information on hotel booking consideration (Gavilan, Avello, \& Navarro, 2018). Furthermore, the role of hotel website in the context of 153 Taiwanese browsers has been positioned as crucial channel for online purchase (Hung, 2017). Li et al observed 298 Chinese respondents via survey to investigate factors affecting particularly in economy hotel website quality on online booking intention in China (Li, Penga, Jiang, \& Law., 2017). It is therefore imperative for this study to develop the evaluation of hotel website quality in the upscale context focusing on Vietnamese online bookers who have experienced hotel website service especially in post-purchase phase before deciding where to stay in Vietnam.

H1: hotel website quality has a positive effect on customer satisfaction

\section{Developing goals for hotel website performance}

Customer perception of hotel website quality

Measuring the effectiveness of customer perspective on the quality of hotel website in general is very useful for researchers and practitioners. The first interaction of lookers with a website impacted their behaviours regarding the service quality offered on website (Jiang, 2016). The crucial of dimensions and attributes on hotel web sites from the perspective of travellers based on two groups of international hotel website users indicated that there was no significant difference in most of the included dimensions and attributes among users (Hsu \& H.C., 2005). The online bookers who are user-generated content with rich source of information from the website of hotels (Li, Ye, \& Law, 2013). The customers would reserve a room or even recommend the website to others if they are content the service quality of the website and in contrast (Li, Ye, \& Law, 2013); The characteristics and relates those characteristics to website performance have been investigated and focused on small and medium size hotels in two developing destinations of the Balearic Islands in Spain and in the South of Brazil. The authors found that websites are using as mass media channel but ignoring the interactivity and one-to-one communication with customers in well advance of sale. (Schmidt, Cantallops, \& Santos, 2008). So the website quality was mentioned such a reservation information (Ma A. L., 2008), and the vital functionality of hotel website (Ip C. L., 2012). However, the hotel website was indirectly influenced by lookers which leads to the extension of customer satisfaction (Belanche, 2012). Abdullah et al. argued through a study of Malaysian hotel websites based on synthesis of literature that there are online visitors but fail to convert it into online bookers. The authors suggested that customer perception on hotel website interactivity influences customer perceived value and intention to revisit the hotel website in the future (Abdullah, Jayaraman, \& Kamal, 2016). The hotel star rating is significantly related to hotel website performance (Salavati, 2015). Eventually, the value customer perceived service and the purpose to revisit in the future are effected by the hotel star rating related to hotel website performance (Abdullah D. J., 2016). Following the practical proposition, we focus on approaches which employ definitions of customer perception on website service quality particularly in luxury hotels.

H2: Customer perception of hotel website has a positive effect on the hotel website service quality

Information and interface of a hotel website provided 
Previous studies have highlighted the role of information and interface of any webpage, especially the tourism and hotel service website where the marketing team can turn lookers to bookers for particular services displayed on the screen. However, to what extent the information should be placed on the interface of hotel website? Martin Fishbein and Icek Ajzen in 1967 developed the theory of reasoned action (TRA) aims to explain the relationship between attitude and behaviours (the A-B relationship). It predicts to that extent the individual would behave regarding their pre-existing attitudes and behavioural intentions. Adapting the benefit of TRA, the website quality has been developed with 12 dimensions and focused on the website interface regarding to the extensive literature review, and interviews with Web designers and Web visitors (Loiacono, Watson, \& Goodhue, 2002). It can be said that website quality is such an instrument on the internet to satisfy customers' need especially on their visual and functionality expectation. Application to service categories, understanding the determinants of consumer's quality perception facilitates a potential starting point to build effective quality management in the e-commerce (Bauer, Hammerschmidt, \& Falk, 2005). It is therefore vital to include both technical and web service such business aspects (Nath \& Singh, 2010). Especially, high-class hotel websites needed to enhance positive user experience through IT advance (Zeng, 2012) due to increase the customer satisfaction positively (Bai B. L., 2008). However, the IT impact service management in up-scale hotels was highlighted in managing customers delight and if they found difficult to use web page or distrust the information displayed on the screen, they properly feel uncomfortable about the service provider (Chathoth, 2007). The hotel websites practised user-unfriendliness and marketing ineffectiveness (Pranic'l, 2014); led to inefficient environmental management regarding to the informational dimension of the websites (Hsieh, 2012). Consequently, boosting the customer satisfaction level needs to focus on both hedonic and utilitarian features (Bilgihan A. B., 2014). Moreover, the website quality constructs should be categorized as security, enjoyment, information quality, ease of use, and service quality (Hasanov, 2015). In Vietnam market, the on line service and mobile devices are available to integrate digital technology by many high-end establishments. According to Grant Thornton's 2016 survey, it reported that $67.3 \%$ of the hotels had already integrated digital technology to their business, compared to $49.3 \%$ in 2015 . The extremely important role of online presence including information and interface is effectively to optimize the performance driven content marketing and quality control. Because technology is such a vital element of their business and a way to set them apart from their competitors.

H3: The Information and interface of a hotel website have a positive effect on hotel website service quality

Trust on hotel website

Consumers' trust in the service providers towards the online platform is one of the central relationship between user-seller. Trust refers to create positive belief in a person or object that is reliability and dependability (Everard \& Galletta, 2014). Any website tries to convince web surfers to stay on the site at least few seconds for the first look, then turns them into bookers as many as possible. A long-term relationships with customers was based on trust in the service industry (Kumar, 1995) and then trust directed customers whether to revisit the hotel website in the future (Abdullah D. J., 2016). Therefore, the hotel websites and its ease of use positively affect e-Trust and online booking intentions later on (Li, Penga, Jiang, \& Law., 2017). However, e-Trust was considered as risk-taking behaviour towards 
consumers' expectations (Morgan, 1994), for instance some viewers neither trust the information nor comments on website (Wasim Ahmad, 2018). Especially leisure travellers prefer to book the rooms on hotel online due to its convenience, cost and time saving (Lien, Wen, Huang, \& Wu, 2015). For instance, Amazon, TripAdvisor, Agoda, Booking, etc. are one of trustworthy sites which are quickly enable customers to trust and purchase with their credit cards from those sites. Furthermore, website content and trust are evidence of assurance on website (Rahimnia, 2013). Consequently, the association of hotel websites and its sustainable progress mission on the up-scale hotel websites should be included the effective content, consistency and trust to customers possible.

H4: Trust has a positive effect on the hotel website service quality

\section{Methodology}

\section{Research model}

The research model consists of the antecedents of customer satisfaction included information and interface customer perception, trust; and investigating the effects of those indicators on hotel website service quality and customer satisfaction and examining the influence of those indicators on those constructs. The proposed model is shown in figure 1

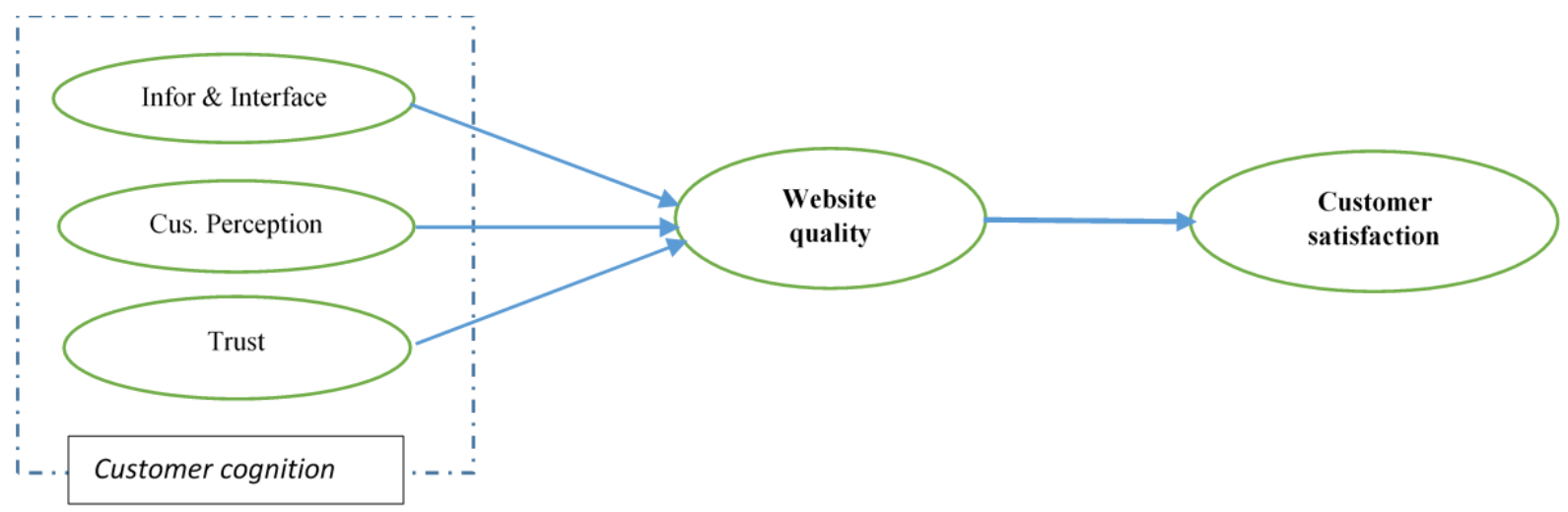

Figure 1. Our research model and the proposed relationships

\section{Data collection}

This research employed online and offline approaches, stratified sampling and sent the questionnaire to 400 domestic and international tourists. This study required the respondents who had stayed a room from 4-star to 5-star hotels within Vietnam in the last 12 months were qualified to participate in the survey. After deleting invalid samples, we randomly recruited 321 samplings and the response rate was $80 \%$. The number of valid observations in the north, middle and south of Vietnam. The number of valid observations in the North, Middle and South of Vietnam were 198 women (61.7\%) and 123 men (38.3\%) aged bracket from 16-25 (27.7\%), 26-35 (41.7\%), 36-45 (26.8\%) and over $45(3.7 \%)$ respectively for the total sample size of 321 . The respondents are used to surf the Internet over 8 hours (33.3\%), from $4-8$ hours (45.8\%) and below 4 hours (20.9\%). The demographic data collected mainly $73.52 \%$ of Asian, $12.77 \%$ of American, $3.12 \%$ of African, $6.54 \%$ of Australian and $4.05 \%$ of European. Vietnam Investment Review reported that Chinese tourists accounted for the majority (4.1 million) among the 7.9 million of foreign tourists to 
Vietnam and $92 \%$ of tourists stayed overnight, $7 \%$ visited the country for one day and more than $60 \%$ organised their trips by themselves in the first six months of 2018 (VNA, 2018). The Vietnamese government expects to make tourism a key economic sector, so the extension of the visa-waiver program to Western European tourists, and the implementation of an e-visa system have been put in place to attract more International tourists come to Vietnam. The Resolution No. 56/NQ-CP (renewed until the 30th June 2021) allows citizens from France, Germany, United Kingdom, Italy, and Spain staying for less than 15 days and meeting certain requirements are exempted from the visa requirement (adapting from the Law 47/2017/QH13 on foreigner's entry into, exit from, transit through and residence in Vietnam). In order to measure the representativeness of the observations in each continent, a goodness-of-fit test was used and the result Sig. ( 2 sided $)=0.504$ is not significant. It means that there is no significant difference between the population percentage and the sample percentage in the five continents.

\section{Survey instrument}

The survey developed with three sections including 14 open and 17 scaling questions. The first section reviewed four information about the hotel website. Next section, respondents' level of perceive hotel website quality, customer cognition of hotel website, and customer satisfaction were measured. Customer perception items were modified from (Abdullah, Jarayaman, \& Kamal, 2016) and (Liu \& al, 2013). Trust items developed by (Li, Penga, Jiang, \& Law., 2017) and (Abdullah, Jarayaman, \& Kamal, 2016). Information and interface items were adapted from (Bilgihan \& Bujisic, 2014). The 17 items were measured by a seven-point Likert scale ranging from "strongly disagree $=1$ " to "strongly agree=7". Last section included demographic questions. The developed questionnaire was pre-tested on 59 domestic tourists and the results showed the instructions and questions were well understood. The questionnaire was tested by mean of results, Cronbach's Alpha (CA) and Exploratory factors (KMO) to analyse the appropriate factors. CA values for all of the factors were acceptable (95\% confidence interval).

\section{Results and Discussions \\ Test of gender differences}

Table 1 shows the mean score and the significance results between males and females in term of five constructs. The outcomes indicated that females and males have no significant differences between males and females on level of satisfaction. Regarding five constructs, the overall means of females are higher means of males.

Table 1. Our test of gender differences

\begin{tabular}{lrrr} 
Measurement & Female & Male & \multicolumn{1}{c}{ Sig. } \\
\hline Items & Mean & Mean & \\
\hline Customer Perception (CP) & & & \\
CP1_Hotel website quality meets one's needs & 5.84 & 4.96 & .000 \\
CP2_Hotel website quality is positively excellence & 5.59 & 5.06 & .000 \\
CP3_Hotel website quality impacts purchase intention & 6.03 & 5.38 & .000 \\
Information \& Interface (II) & & & \\
II1_Hotel website quality is security & 5.98 & 4.78 & .000
\end{tabular}


II2_Hotel website quality is enjoyment

II3_Hotel website quality is information quality

II4_Hotel website quality is ease of use

Trust (T)

T1_Hotel website must establish trust relationship with

online customers

T2_Hotel website affects willingness to book room online

T3_Hotel website influence intention to revisit hotel website

Website service quality (SQ)

SQ1_Hotel website quality is service quality

SQ2_Price on hotel website is higher than other channels

SQ3_Be satisfied to book a room on hotel website

SQ4_Online service of hotel is useful and effective

Customer Satisfaction (CS)

CS1_Be satisfied with hotel website

CS2_Keep booking a room on hotel website

CS3_Be happy with the online service of the hotel

\begin{tabular}{lll}
6.14 & 5.52 & .000 \\
6.28 & 5.41 & .000 \\
6.32 & 5.40 & .000 \\
& & \\
6.14 & 5.68 & .000 \\
6.06 & 5.49 & .000 \\
6.19 & 5.52 & .000 \\
& & \\
5.76 & 5.47 & .015 \\
5.22 & 5.39 & .025 \\
5.72 & 4.80 & .004 \\
5.47 & 4.98 & .004 \\
& & \\
5.44 & 5.01 & .000 \\
5.03 & 4.82 & .002 \\
5.46 & 5.06 & .000 \\
\hline
\end{tabular}

Source: Authors' own source

\section{Descriptive analysis of bookings on 4 and 5-star hotel websites}

This study collected the motivation of respondents who are content with the service quality of hotel website. The major reasons to book the room on hotel website are $12 \%$ of "nice images", $11.3 \%$ of "ease and functional interface", $8.3 \%$ "booking directly through hotel website to be offered more benefits" and so on. There are many ways to increase hotel website' productivity and efficiency and to deliver memorable experiences to online searchers. In fact, customers want to keep in touch online of a finger and access continuously the services and information they need. Compared with loosen booking intention on hotel website, $37 \%$ of the total respondents as likely to be alert. Another study said that $25 \%$ of online hotel bookers do not trust or interest in direct booking on hotel website (Ahmad \& Sun, 2018). It is therefore imperative for hotel management to leverage the effective function of hotel website service. Consequently, Marriot and Starwood started in 2015 with campaign "it pays to book direct" in order to lower its member rates; Hilton in 2016 launched its huge marketing activity ever with "stop clicking around" campaign to extend direct-booking discounts to all loyalty members; Hyatt in 2017 gave away 10\% discount for Hyatt Gold Passport members with direct booking (Howe, 2017). More particularly, the higher number of direct booking with hotel, especially on the webpage itself, the lower level of commissions paid for online travel agencies (OTAs) and the partnership is a no-brainer for hotels (Anderson, 2009). Normally, the OTAs take 15-30 percent of the value of the length of stay (Clampet, 2016). Therefore, hotel revenue could take this "free" marketing and deal with unsold inventory.

According to a research report of EU-Vietnam Business Network, Vietnam turns to a travel destination in Asian since 2012 because of its growing popularity and its number of inbound tourists. The tourism industry increased from 6.8 million to 13 million tourists from 2012 to 2017, at a Compounded Annual Growth Rate of 13.5\% over five years (Anonymous, 2018). Besides increasing number of inbound tourists to reach 20 million from 2017 to 2020, domestic travels have been promoted by the programme called "Vietnamese Travel in Vietnam - Each Journey to Love the Fatherland More". Consequently, the Vietnam National 
Administration of Tourism reported an estimated 70 million domestic tourists, indicating a CAGR growth of $16.6 \%$ between 2012 and 2017 and welcomed 82.9 million domestic and international visitors, over double the number of visitors in 2012.

The accommodation industry grows with tourism progress. More particularly, the number of 4 to 5 -star hotels increased of $10 \%$ in 2016. This demand upward drives both local (domestic tourists) and foreign (inbound tourists) tourism. As the increasing of income, domestic travellers find interesting more and more in luxury hotels. Furthermore, foreign visitors are more price sensitive and seek higher-end hotels to stay in Vietnam, whether for leisure or business purposes. Many well-known international and domestic hotel brands have established a presence in Vietnam. The majority hotels in Vietnam are operated in the South mainly in Hochiminh city. The highest number of total 306 luxury hotels are located in this zone (Anonymous, Vietnamnet , 2017) Consequently, the room booking respondents in this study were inn this biggest and most developed city in the country such as from the North, the Central to the South at $3(6 \%), 16(33 \%)$ and $29(60 \%)$ respectively. The study found 17 hotel groups worked well in their websites performance to convert searchers to bookers included International worldwide groups to national hotel groups. The top three international and domestic hotel groups were Accor, Saigon Tourist Holding Company and Marriot/Starwood with the booking times at 33,12 and 11 respectively regarding incentive information, friendly usage and especially booking procedure is safe and convenience for online bookers on contemporary interface of hotel websites. Continuously, Accor group with 21 number of establishments is the leading hotel management group in Vietnam (Anonymous, 2018). According to EVBN, Accor group is the representative for 5 first international hotel groups in Vietnam, followed with Intercontinental Hotel groups (IHG) (account for 21 number of establishments), Marriot and Starwood (has 7 number of establishments) and Hyatt hotels (with 2 number of establishments). In this study, the 25/48 (52\%) domestic hotels in this observation impressed the bookers on their hotel websites (see table 2). Saigon Tourist Holding Company is biggest hotels and resorts groups in Vietnam with 54 hotels, 13 resorts and complexes throughout Vietnam region. (Anonymous, 2018)

\section{Test of Exploratory Factor Analysis (EFA)}

The overall CA of independent variables of hotel websites were significantly associated with each other from 0.838 to 0.914 , the KMO was 0.866 (Hair at al., 2006). However, the values of CA of all dependent variables were lower than independent variables at 0.874 for KMO (i.e. service quality and customer satisfaction). The Sig of Chi-Square were appropriate at 0.000. The observed latent variables were grouped into one component and converged in one iteration. All loading factor of these variables had greater than 0.5 . Therefore, all these variables are substantially loaded for further analysis with respect to Correlation Matrix.

The results show that Pearson Sig. (2-tailed) correlation between independent variables and dependent variables were completely zero and had a linear relationship with each other. The correlation of II and T was significantly strongest of $r=0.844$, but weakest with a coefficient of $\mathrm{r}=0.476$ was between II and website service quality. The independent variables introduced into the regression run affected $64.2 \%$ of the variance of the dependent variable and the remaining 35.8\% was due to exogenous variables and random errors at adjusted R2 value of 0.642 . There was no autocorrelation occurrence at 1.637 respected to 
the value of Durbin coefficient - Watson in the range of 1.5 to 2.5. The ANOVA resulted statistically significant $p$-value i.e. $p=0.000(p<0.05)$ and $F=192.508$. Therefore, the multiple linear regression models are suitable for data sets and can be used. According to Sig testing of the regression coefficient of the $\mathrm{CP}, \mathrm{II}$, and $\mathrm{T}$ independent variables, the results were zero for all, but II beta was at -0.570 . So, the II independent variable was the explanation for the dependent variables, II variable was excluded from the model. There are multi-linearity occurrences because the VIF coefficients of the independent variables were higher than 2 . The regression coefficient of $\mathrm{CP}$ and $\mathrm{T}$ was greater than 0 and incorporated into the regression analysis to affect the SQ dependent variable. The normal distribution hypothesis of the remainder, the scatter plot of SQ assumed linear relations and the normal P-P plot of regression standardized residual of SQ were not violated (SQ_Service quality had Mean = 4.66E-15).

\section{Hypotheses testing}

The four hypotheses have accepted by data. The variables of hotel websites were supported by Information \& Interface (II), Customer Perception (CP), Trust (T), Website Service Quality (SQ) and Customer Satisfaction (CS). So, the output has its standardized regression:

$\mathrm{SQ}=0.484 * \mathrm{II}+0.74 * \mathrm{CP}+0.642 * \mathrm{~T}$

$\mathrm{CS}=0.797 * \mathrm{SQ}$

$\rightarrow$ Customer satisfaction $=0.797 *(0.484 * \mathrm{II}+0.74 * \mathrm{CP}+0.642 * \mathrm{~T})$

In sum, the hypothesized model exhibits a good fit with the data collected. The highest value to others effecting hotel website service quality was customer perception factor $\left(\mathrm{R}^{2}=0.546\right.$ and $\left.\beta=0.74\right)$. The association between customer satisfaction and hotel website service quality was significantly highest $\left(\mathrm{R}^{2}=0.635\right.$ and $\left.\beta=0.797\right)$. In other words, enhancing hotel website service quality was the value added of the degree of customer satisfaction.

\section{Conclusion and Implication}

This study contributes to the literature in examining the factors effect online bookers including customer perception, information and trust on hotel website service quality and customer satisfaction particularly in 4 and 5-star hotels; and comparing gender differences in these constructs. The results confirm most of the path effects showing that customer perception, information and trust on hotel website positively influence perceived website quality and customer satisfaction. Customer perception of hotel website quality has a most significant impact on level of satisfaction.

In terms of the overall mean of five constructs, tourists believe that they would have more benefits when booking on hotel website, the hotel website is trustworthy, and the hotel would offer discount or better price for them. In comparison with males, females had higher rating for perception, trust and expectation for website interface with incentive information. Consequently, females had higher level of agreements on service quality, and satisfaction. This result is consistent with the study of (Lien, Wen, Huang, \& Wu, 2015). Reflecting the reality that female consumers in Vietnam are relatively price sensitive and concerned about reliability. Males are more easily convinced to accept hotel website quality and satisfaction than females. However, the differences are not significant between males and females on these constructs, indicating an inconsistency with findings of previous studies. One possible 
reason is that most males and females in the sample are well-educated and part of the Internet generation

This study provides hoteliers a theoretical basis for the venue that offering nice images, ease and functional interface and more benefits for booking directly through hotel website in order to increase level of customer satisfaction towards perceive hotel websites service quality on 4-star and 5-star. The hotel managers needs to understand customer's expectation and perception value towards the hotel websites. To increase consumer perception of hotel brand with effective website, the hotel can consider providing competitive rates or discounts for direct booking. To increase customer satisfaction, hotels should offer complete product information and package online and improve visual displayed with incentive information, friendly interface with safety web page. Building trust on online bookers is set to become a vital factor in obtaining customer satisfaction to hotel brand names as always.

Findings and conclusion of this study should be interpreted carefully in line with the hotel booking platform for future study. Some limitations are not well grounded such as unavailability and inaccessibility of data, time and budget constraints of the researcher and some other practical concerns. Acknowledging these limitations, for future research, we suggest other possible determinants to observe, such as booking intention, room rate strategy, etc. might be important factors influencing the hotel website performance and customer satisfaction.

Acknowledgement: The research for this paper was financially supported by the Internal Grant Agency of Faculty of Management and Economics, Tomas Bata University in Zlin, Grant no.IGA/FaME/2018/009

\section{References}

\section{Journals}

Abdullah, D., Jayaraman, K., \& Kamal, S. B. (2016). A Conceptual Model of Interactive Hotel Website: The Role of Perceived Website Interactivity and Customer Perceived Value Toward Website Revisit Intention. Procedia Economics and Finance , 37, 170-175. doi:10.1016/S2212-5671(16)30109-5

Ahmad, W., \& Sun, J. (2018). Modeling consumer distrust of online hotel reviews. International Journal of Hospitality Management, 71, 77-90. doi:10.1016/j.ijhm.2017.12.005

Albert A. Barreda, A. B. (2016). Online branding: Development of hotel branding through interactivity theory. Tourism Management, 57, 180-192. doi:10.1016/j.tourman.2016.06.007

Anderson, C. (2009). The billboard effect: Online travel agent impact on non-OTA reservation volume . Electronic article, Cornell Hospitality Report. doi:https://scholarship.sha.cornell.edu/chrpubs/2/

Ariff, M., Yan, N., Zakuan, N., Rahim, K., \& Ismail, K. (2014). Online purchasing behavior of Malaysia's young consumers. In S. K. Ford Lumban Gaol (Ed.), Recent Trends in Social and Behaviour Sciences (p. 8). Group, Taylor \& Francis. 
Aurelio Mauri, R. M. (2013). Web reviews influence on expectations and purchasing intentions of hotel potential customers. International Journal of Hospitality Management, 34, 99-107. doi:10.1016/j.ijhm.2013.02.012

Bai, B., Law, R., \& Wen, I. (2008). The impact of website quality on customer satisfaction and purchase intentions: Evidence from Chinese online visitors. International Journal of Hospitality Management, 27, 391-402. doi:doi:10.1016/j.ijhm.2007.10.008

Bauer, H. H., Hammerschmidt, M., \& Falk, T. (2005). Measuring the quality of e-banking portals. International Journal of Bank Marketing , 23, 153-175. doi:10.1108/02652320510584395

Belanche, D. C. (2012). Website quality, consumer satisfaction and the intention to use a website: the moderating effect ofperceived risk. J. Retailing Consum. Serv., 19(1), 24132.

Ben Haobin Ye, A. A. (2017). Website interactivity and brand development of online travel agencies in China: The moderating role of age. Journal of Business Research. doi:10.1016/j.jbusres.2017.09.046

Beverley A. Sparks, V. B. (2011). The impact of online reviews on hotel booking intentions and perception of trust. Tourism Management, 33, 1310-1323. doi:10.1016/j.tourman.2010.12.011

Bilgihan, A. B. (2014). The effect of website features in online relationship marketing: A case of online hotel booking. Electronic Commerce Research and Applications. Retrieved from Electronic Commerce Research and Applications.

Bowen, J. T., \& Chen, S.-L. (2001). The relationship between customer loyalty and customer satisfaction. International Journal of Contemporary Hospitality Management, 13(5), 213 - 217. doi:https://doi.org/10.1108/09596110110395893

Chathoth, P. K. (2007). The impact of information technology on hotel operations, service management and transaction costs: A conceptual framework for full-service hotel firms. International Journal of Hospitality Management, 26, 395-408. doi:10.1016/j.ijhm.2006.03.004

Chetty, P., \& Datt, S. (2015, 2 6). One way ANOVA test in SPSS. Retrieved from projectguru: https://www.projectguru.in/publications/one-way-anova-test-spss/

Chunyu Li, G. C. (2017). The signaling effect of management response in engaging customers: A study of the hotel industry. Tourism Management, 62, 42-53. doi:10.1016/j.tourman.2017.03.009

Clampet, J. (2016, 4 25). Everything You Wanted to Know About the Hotel Industry's Gripes Against OTAs. Retrieved 6 25, 2018, from skift: https://skift.com/2016/04/25/everything-you-ever-wanted-to-know-about-hotelindustrys-complaints-against-otas/

Dandison C. Ukpabi, H. K. (2016). Consumers' acceptance of information and communications technology in tourism:. Telematics and Informatics. doi:http://dx.doi.org/10.1016/j.tele.

Davidow, H., \& Uttal, B. (1989). Service Companies: Focus or Falter. Harvard Business Review, 77-85. 
Díaz, E., \& Koutra, C. (2013). Evaluation of the Persuasive Features of Hotel Chains Websites: A Latent Class Segmentation Analysis. International Journal of Hospitality Management.

Everard, A., \& Galletta, D. F. (2014). How Presentation Flaws Affect Perceived Site Quality, Trust, and Intention to Purchase from an Online Store. Journal of Management Information Systems, 22, 56-95. doi:10.2753/MIS0742-1222220303

Ferguson, J. L. (2014). Implementing price increases in turbulent economies: Pricing approaches for reducing perceptions of price unfairness. Journal of Business Research, 67, 2732-2737. doi:10.1016/j.jbusres.2013.03.023

Françoise Simona, V. T. (2018). Does brand-consumer social sharing matter? A relational framework of customer engagement to brand-hosted social media. Journal of Business Research, 85, 175-184. doi:10.1016/j.jbusres.2017.12.050

Gavilan, D., Avello, M., \& Navarro, G. M. (2018). The influence of online ratings and reviews on hotel booking. Tourism Management, 66, $53 \mathrm{e} 61$. doi:10.1016/j.tourman.2017.10.018

Hair Jr, J. F. (2014). Partialleast squares structural equation modeling (PLS-SEM): An emerging tool in business research. European Business Review, 26(2), 106 - 121.

Hair, J. F. (2011). PLS-SEM: Indeed a Silver Bullet. The Journal of Marketing Theory and Practice, 19(2), 139-152. doi:10.2753/MTP1069-6679190202

Hasanov, J. K. (2015). The impact of website quality on online purchaseintention of organic food in Malaysia: a WebQual Model approach. Proc.Comput. Sci., 72, 382-389.

Howe, N. (2017, 7 31). Hotels Versus OTAs: Who Is Winning Over Millennial Travelers. Retrieved from forbes: https://www.forbes.com/sites/neilhowe/2017/07/31/hotels-versus-otas-who-iswinning-over-millennial-travelers/\#191a9bc9277a

Hsieh, Y. (2012). Hotel companies' environmental policies and practices: a contentanalysis of their web pages. Int. J. Contemp. Hospitality Manage, 24, 97-121.

Hsu, R. L., \& H.C., C. (2005). Customers' perceptions on the importance of hotel web site dimensions and attributes. (E. G. Limited, Ed.) International Journal of Contemporary Hospitality Management, 17, 493-503. doi:DOI 10.1108/09596110510612130

Hung, C.-L. (2017). Online positioning through website service quality: A case of star-rated hotels in Taiwan. Journal of Hospitality and Tourism Management, 31, 181-188. doi:10.1016/j.jhtm.2016.12.004

Ip, C., Law, R., \& Lee, H. “. (2012). The Evaluation of Hotel Website Functionality by Fuzzy Analytic Hierarchy Process. Journal of Travel \& Tourism Marketing, 29, 263-278. doi:10.1080/10548408.2012.666173

Irene Cheng Chu Chan, L. W. (2017). The effect of online reviews on hotel booking intention: The role of. International Journal of Hospitality Management, 66, 54-65. doi:10.1016/j.ijhm.2017.06.007

Jeong, M., Oh, H., \& Gregoire, M. (2003). Conceptualizing Web site quality and its consequences in the lodging industry. Hospitality Management, 22, 161-175. doi:10.1016/S0278-4319(03)00016-1 
Jiang, Z. W. (2016). ., 2016. The determinants and impacts ofaesthetics in users' first interaction with websites. J. Manage. Inf. Syst, 33(1), 229-259.

Kumar, N. S. (1995). The effects of perceivedinterdependence on dealer attitudes? J. Mark. Res., 32(3), 348-356.

Ladhari, R., \& Michaud, M. (2015). eWOM effects on hotel booking intentions, attitudes, trust, and website perceptions. International Journal of Hospitality Management, 46, 36-45. doi:10.1016/j.ijhm.2015.01.010

Lee, C. H. (2014). Toward understanding consumer processing of negative online word-ofmouth communication: The roles of opinion consensus and organizational response strategies. Journal of Hospitality \&Tourism Research, 38, 330-360.

Lee, J., \& Morrison, A. M. (2010). A comparative study of web site. Journal of Hospitality and Tourism Technology, 1, 50-67. doi:DOI 10.1108/17579881011023016

Lee, Y. L. (2010). An empirical investigation of electronic word-of-mouth: Informational motive and corporate response strategy. Computers in Human Behavior, 26, 10731080.

Li, H., Ye, Q., \& Law, R. (2013). Determinants of Customer Satisfaction in the Hotel Industry: An Application of Online Review Analysis. Asia Pacific Journal of Tourism Research, 18, 784-802. doi:10.1080/10941665.2012.708351

Li, L., Peng, M., Jiang, N., \& Law, R. (2017). An empirical study on the influence of economy hotel website quality on online booking intentions. International Journal of Hospitality Management, 63, 1-10. doi:https://doi.org/10.1016/j.ijhm.2017.01.001

Lien, C.-H., Wen, M.-J., Huang, L.-C., \& Wu, K.-L. (2015). Online hotel booking: The effects of brand image, price, trust and value on purchase intentions. Asia Pacific Management Review, 1-9. doi:10.1016/j.apmrv.2015.03.005

Linda D. Hollebeek, M. S. (2014). Consumer Brand Engagement in Social Media: Conceptualization, Scale Development and Validation. Journal of Interactive Marketing , 28, 149-165. doi:10.1016/j.intmar.2013.12.002

Linlin Liua, M. K. (2018). Trust transfer in social media brand communities: The role of consumer engagement. International Journal of Information Management, 41, 1-13. doi:10.1016/j.ijinfomgt.2018.02.006

Liu, \& al, e. (2013). Analyzing changes in hotel customers' expectations by trip mode. International Journal of Hospitality Management, 34, 359-371.

Liu, C., Arnett, K. P., \& Litecky, C. (2000). Design Quality of Websites for Electronic Commerce: Fortune 1000 Webmasters' Evaluations. 10(2), 120-129.

Liu, J. N., \& Zhang, E. Y. (2014). An investigation of factors affecting customer selection of online hotel. International Journal of Hospitality Management, 39, 71-83. doi:10.1016/j.ijhm.2014.01.011

Liua, M. T., Wong, I. A., Tseng, T.-H., Chang, A. W.-Y., \& Phau, I. (2017). Applying consumerbased brand equity in luxury hotel branding. Journal of Business Research . doi:10.1016/j.jbusres.2017.06.014 
Liuyi Ling, X. G. (2014). Opening the online marketplace: An examination of hotel pricing and travel agency on-line distribution of rooms. Tourism Management, 45, 234-243. doi:10.1016/j.tourman.2014.05.003

Loiacono, E. T., Watson, R. T., \& Goodhue, D. L. (2002). WEBQUAL: A MEASURE OF WEBSITE QUALITY. AMA Winter Conference. . Austin, TX.

Luis V. Casalóa, C. F. (2015). Do online hotel rating schemes influence booking behaviors? International Journal of Hospitality Management, 49, 28-36.

Ma, A., Law, R., \& Ye, Q. (2008). The functionality of the performance of international chain hotel websites in Hong Kong, Shanghai and Beijing. Asian journal of tourism and hospitality research, 2, 13-24. Retrieved from http://hdl.handle.net/10397/63802

Martín, H. S., \& Herrero, Á. (2012). Influence of the user's psychological factors on the online purchase intention in rural tourism: Integrating innovativeness to the UTAUT framework. Tourism Management, 33(2), 341-350. doi:https://doi.org/10.1016/j.tourman.2011.04.003

Martin-Fuentes, E. (2016). Are guests of the same opinion as the hotel star-rate classification system? Journal of Hospitality and Tourism Management, 29, 126-134. doi:10.1016/j.jhtm.2016.06.006

Matthew Tingchi Liua, I. A.-H.-Y. (2017). Applying consumer-based brand equity in luxury hotel branding. Journal of Business Research. doi:10.1016/j.jbusres.2017.06.014

McMullan, R., \& Gilmore, A. (2008). Customer loyalty: an empirical study. European Journal of Marketing, 42, 1084-1094. doi:https://doi.org/10.1108/03090560810891154

Morgan, R. H. (1994). The commitment-trust theory of relationshipmarketing. J. Mark., 58(3), 20-38.

Nath, A., \& Singh, R. (2010). Evaluating the Performance and Quality of Web Services in Electronic Marketplaces. The 15th Americas Conference on Information Systems, AMCIS 2009, 7, pp. 43-59. San Francisco, California, USA.

Patrick , P. D., Sophie , T. v., \& Christian , H. (2018). Digital marketing strategies, online reviews and hotel performance. International Journal of Hospitality Management, 17, 47-55. doi:10.1016/j.ijhm.2018.01.003

Pei-Ju Lee, Y.-H. H.-T. (2018). Assessing the helpfulness of online hotel reviews: A classification-based approach. Telematics and Informatics. doi:10.1016/j.tele.2018.01.001

Pranic'1, L. P. (2014). Hotel website performance evidencefrom a transition country. Tourism Hospitality Managent, 20 , 45-60.

Priya, C., \& Sharma, P. (2015, 1 9). Linear regression analysis using SPSS. Retrieved from projectguru: $\quad$ https://www.projectguru.in/publications/17-linear-regressionanalysis/

Rahimnia, F. H. (2013). The impact of website content dimensionand eTrust on e-marketing effectiveness: the case of Iranian commercialsaffron corporations. Inf. Manage, 50, 240-247.

Rianthong, N., Dumrongsiri, A., \& Kohda, Y. (2016). Optimizing customer searching experience of online hotel booking by sequencing hotel choices and selecting online 
reviews: A mathematical model approach. Tourism Management Perspectives, 20, 5565. doi:10.1016/j.tmp.2016.07.003

Salavati, s. H. (2015). Website adoption and performance by Iranian hotels. Tourism Manage, $46,367-374$.

Schmidt, S., Cantallops, A. S., \& Santos, C. P. (2008). The characteristics of hotel websites and their implications for website effectiveness. International Journal of Hospitality Management, 27, 504-516. doi:10.1016/j.ijhm.2007.08.002

Soyoung Boo, J. A. (2018). Meeting planners' online reviews of destination hotels: A twofold content analysis approach. Tourism Management, 66, 287-301. doi:10.1016/j.tourman.2017.11.014

Sparks, B. A. (2016). Responding to negative online reviews: The effects of hotel responses on customer inferences of trust andconcern. Tourism Management, 53, 74-85.

Thomas Reimer, M. B. (2018). Not just for the recommender: How eWOM incentives influence the. (Elsevier, Ed.) Journal of Business Research, 86, 11-21. doi:10.1016/j.jbusres.2018.01.041

Tijana Radojevic, N. S. (2017). Inside the Rating Scores: A Multilevel Analysis of the Factors Influencing Customer Satisfaction in the Hotel Industry. Cornel Hospitality . doi:10.1177/1938965516686114

Wang, L., Lawa, R., Guillet, B. D., Hung, K., \& Fong, D. K. (2015). Impact of hotel website quality on online booking intentions: eTrust as a mediator. International Journal of Hospitality Management, 47, 108-115. doi:10.1016/j.ijhm.2015.03.012

Wei Wei, L. M. (2013). Customer engagement behaviors and hotel responses. International Journal of Hospitality Management, 33, 316-330. doi:10.1016/j.ijhm.2012.10.002

Wen-Chih Chiou, C.-C. L. (2011). A strategic website evaluation of online travel agencies. Tourism Management, 32, 1463-1473. doi:10.1016/j.tourman.2010.12.007

Xiang, Z., \& Gretzel, U. (2010). Role of social media in online travel information search. (Elsevier, Ed.) Tourism Management, 179-188. doi:10.1016/j.tourman.2009.02.016

Xiaolong Guo, X. Z. (2014). Online coopetition between hotels and online travel agencies: From the perspective of cash back after stay. Tourism Management Perspectives, 12, 104-112. doi:10.1016/j.tmp.2014.09.005

Xiaolong Guoa, L. L. (2013). Optimal pricing strategy based on market segmentation for service products using online reservation systems: An application to hotel rooms. International Journal of Hospitality Management, 35, 274-281. doi:10.1016/j.ijhm.2013.07.001

Yeung, T. A., \& Law, R. (2006). Evaluation of Usability: A Study of Hotel Web Sites in Hong Kong. Journal of Hospitality \& Tourism Research, 30, 452-473. doi:https://doi.org/10.1177/1096348006290115

Zeithaml, V., Parasuraman, A., \& L.L.Berry. (1990). Delivering quality service: Balancing customer perceptions and expectations. New York, USA: The Free Press.

Zeng, L. P. (2012). User-based assessment of websitecreativity: a review and appraisal. Behav. Inform. Technol., 31(4), 383-400. 
Zhao, Y., Xu, X., \& Wang, M. (2018). Predicting overall customer satisfaction: Big data evidence from hotel online. International Journal of Hospitality Management, 111121. doi:10.1016/j.ijhm.2018.03.017

\section{Websites}

Anonymous. (2017, 06 01). Vietnamnet. Retrieved from Over 345 million in FDI poured into property: http://english.vietnamnet.vn/fms/business/173737/over--345-millionin-fdi-poured-into-property-sector.html.

Anonymous. (2017, 6). Vietnamnews. Retrieved 12 2018, from Vietnamnews: http://vietnamnews.vn/life-style/379600/viet-nam-seeks-way-to-boost-onlinetravel-market.html\#sUFM0jAwsaQ5Glck.99

Anonymous. (2018). Hospitality sector - EVBN The Hospitality market in Vietnam. Vietnam: EU-Vietnam business network. Retrieved 2018, from file:///E:/hoc\%20PhD/hoc\%20PhD/publication/zlin\%20_2018/vietnam\%20repor t/EVBN_Hospitality-Final_Report-Update-180517.pdf

Anonymous. (2018). statista. Retrieved 12 2018, from https://www.statista.com/outlook/262/100/online-travel-booking/worldwide

Anonymous. (2018). Statista. Retrieved 12 2018, from https://www.statista.com/outlook/267/100/hotels/worldwide

Anonymous. (2018). Statista. Retrieved 9 2018, from https://www.statista.com/outlook/262/127/online-travel-booking/vietnam

Anonymous. (2018). Statistica. Retrieved https://www.statista.com/outlook/262/127/online-travel-booking/vietnam.

McDonald, N. (2018). we are social. Retrieved 12 2018, from https://wearesocial.com/us/blog/2018/01/global-digital-report-2018

VNA. (2018, July 7). Foreign tourism to Vietnam surges. Retrieved October 16, 2018, from Vietnam Investment Review: https://www.vir.com.vn/foreign-tourism-to-vietnamsurges-60796.html 